\title{
EFFECT OF COOPERATIVE LEARNING MODEL TYPE TEAM GAME TOURNAMENT (TGT) ON CROSS-CULTURAL SKILLS IN LEARNING SCIENCE SOCIAL KNOWLEDGE IN PRIMARY SCHOOL
}

${ }^{1}$ Galih Dani Septiyan Rahayu and ${ }^{2}$ Febby Fajar Nugraha

\author{
${ }^{1}$ IKIP SILIWANGI \\ ${ }^{2}$ UNIVERSITAS KUNINGAN \\ ${ }^{1}$ galih040990@ikpsiliwangi.ac.id \\ 2febbyfajarnugraha@gmail.com
}

\begin{abstract}
The purpose of this research is to know the influence of cooperative model of game tournment team (TGT) type to cross cultural skill in IPS learning in fourth grade of SD Negeri Talaga kulon I. The method used in this research is pre experiment with one group pretest-posttest research design with instrument is a checklist observation system guidance. The result of this research is TGT type cooperative model have an effect on the improvement of cross cultural skills of elementary school students of Talaga Kulon I. This is seen from the comparison of pretest and posttest score and statistical test showing improvement especially on indicators "Harnessing social and cultural differences to work together effectively".

Keywords: Game team tournament model and cross cultural skills
\end{abstract}

\section{INTRODUCTION}

Indonesia is one of the diverse countries seen from various aspects such as culture, language, ethnicity, religion, and so forth. One of the factors that make Indonesia rich in its diversity is the vast area of Indonesia that stretches from Sabang to Merauke. The vastness of Indonesia's territory and diversity has its own advantages for the Indonesian state as well as the love of the homeland, its uniqueness compared to other countries, and the attraction for foreign citizens. The above things can happen if diversity in Indonesia continues to be preserved and introduced to other countries. However, this will not happen if Indonesian citizens themselves do not recognize diversity, do not value diversity, and do not introduce diversity to other countries. Challenges continue to emerge related to preserving Indonesia's diversity such as technological developments, industrial developments and developments in other fields in this era of globalization.

In the globals era, challenges related to preserving Indonesian diversity include easy entry of foreign cultures from foreign countries, the number of television shows, songs, shows, and advertisements that do not show diversity in Indonesia, as well as the number of games and social media apps that make children less likely to communicate with other children in the real world. These factors have an impact on the low level of cross-cultural skills in Indonesia especially in urban areas. As for cross-cultural skills according to 
Partnership for 21st Century Skills Trilling and Fadel (2009, pp. 81) there are several crosscultural skills that must be possessed by students as follows. Interact effectively with others

1. Know when it's appropiate to listen and when to speak

2. Conduct themselves in a respectable, proffesional maner

3. Work effectively in Verse teams

4. Respect cultural differences and work effects with the range of social and cultural backgrounds

5. Open-mindedly respond to different ideas and values

6. Leverage social and cultural differences to create new ideas and increase innovation and quality of work.

The problem of low cross-cultural skills triggered the emergence of other problems such as those occurring from 2013-2015 in some regions of Indonesia as proposed by the Ministry of Home Affairs in Heru (2017) are as follows.

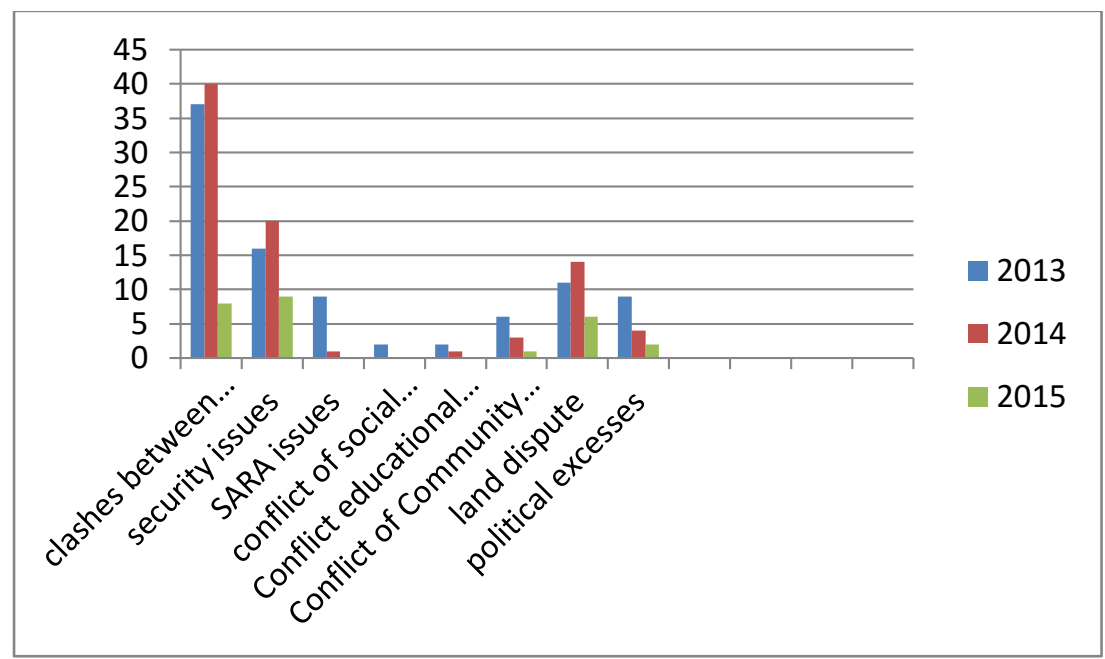

Figure 1. Conflict Occurring in 2013, 2014, and 2015

Based on the data of problems related to cross-cultural skills, it can be done several things to improve it such as introducing and practicing cross-cultured skills that have been exposed from an early age in elementary school (SD) with menggunkaan models that are innovative. Based on the above problems the problem formulation in this study is "Are there any significant improvements in cross-cultural skills of students in the IPS learning of cultural diversity in Indonesia by using cooperative learning model of game tournament (TGT) team type?".

The purpose of this study is to find out whether there is a significant increase in crosscultural skills of students in the IPS lesson of cultural diversity in Indonesia by using cooperative learning model of game tournament (TGT) team type. Some of the benefits derived from the results of this study are: 
1. Academic Benefits

a. Providing inputs to education stakeholders for consideration in formulating specific education policies for IPS subjects.

b. As an input for teachers to make cooperative model of game tournament team type (TGT) as an alternative to be developed and set in implementing IPS learning.

2. Practical Benefits

a. Providing inputs in improving students' social skills, especially cross-cultural skills and improving student learning outcomes in IPS learning.

b. Providing inputs to improving the effectiveness of IPS learning.

c. Providing input for teachers how to apply cooperative learning type of game tournament (TGT) team in IPS learning.

\section{Team Game Tournament Learning (TGT)}

The cooperative model of the tournamnet game team type (TGT) is a learning model that emphasizes student activity, in line with which Slavin (2015) TGT is learning that uses an academy tournament, and uses quizzes and an individual progress scoring system, where students competing as their team representatives with other team members whose previous academic performance was equivalent to theirs. In this learning the teacher only as facilitator and mentor. In learning using this model students are invited to interact more with other students. Galih (2017) proposed the TGT learning stages, namely the delivery of the material concept from the teacher, the division of the group, the students were divided into several heterogeneous groups both from gender factors, intelligence level, and student background to perform games aimed at facilitating students in understand the material presented by the teacher. After students perform the game each group sends their representatives to the tournament.

Viewed from the TGT learning stages described, the TGT model Can be used as a solution to improve the cross culural skills of students because in this TGT model students will interact with many other students so that students skills can be trained at all stages of learning using TGT model.

\section{Cross Cultural Skills}

Indonesia's diversity is a potential for its people when the community is able to live side by side and be peaceful with its diversity. In the 21 st century there are human beings capable of interacting and cooperating with other human beings without differentiating from various factors. In making decisions and solving problems people can not do it themselves but need the help and guidance of others so that mutual respect and able to work together is very important owned by every human apalgi in a country that bergam like Indonesia. One of the skills to make this happen is cross cultural skill. Skills This is in line with what Trilling 
Fadel (2009) proposes, that understanding and accommodating social and cultural differences and being able to use them to create creative ideas and solutions to a problem will be an important skill of the century.

The cross-cultural skill according to Partnership For 21st Century Skill (2008) and Gertsen (Johnson et al, 2006) is a cross-cultural skill development and knowledge consisting of three dimensions of attitude, personality, and behavior through experience that will lead to complex and solvent schemes problems as well as building unity and unity.

\section{METHODS}

This research was conducted in class IV SDN Talaga kulon I Kec. Talaga Kab. Majalengka With 36 research subjects consisting of 12 male students and 24 female students. The method used in this research is pre experiment with one group pretest-posttest research design. According to Soegeng (2016) pre experimental research with one group pretestposttest design is a research using minimal control with design drawing is as follows

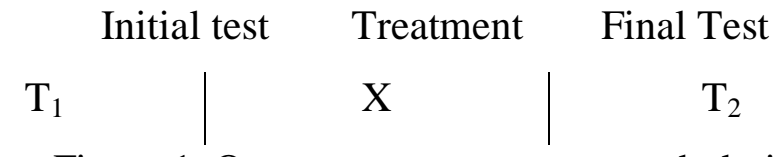

Figure 1. One-pretest-posttest research design

From Figure 1. Soegeng (2016) explains that the steps of one group pretest-posttest design are as follows.

1. Perform the initial test (T1) to measure the average score that students get before the students get treatment by using the game team tournament model (TGT).

2. Give treatment $(\mathrm{X})$ which in this study is a model of learning game tournament team (TGT) in an effort to improve cross-cultural skills.

3. Conduct a final test (T2) to measure the average score obtained after using the game team tournament learning model (TGT).

4. Comparing T1 with T2 to see whether there is a difference in cross-cultural skills before treatment is given after treatment is given.

5. Conduct appropriate statistical tests to see significant differences.

6. Provide iterpretation or meaning of research results.

Data collection techniques conducted in this study using cross-cultural skills questionnaire tools based on Partnership for 21st Century Skills in the form of a pretest and posttest questionnaire with a total of 18 statements to see students' cross-cultural skills. Before the instrument is used, instrument test is done to the expert so that the instrument used is really in accordance with the needs and can answer the objective problem formulations so 
that the valid results are obtained related to cross-cultural skills. The pretest and posttest data obtained in the test with the stage of analyzing the results of pretest, postes and N-gain crosscultural skills of students who then performed statistical processing to see the difference between skills before treatment is given and after being treated in the form of learning model teams game tournament (TGT).

\section{RESULTS AND DISCUSSION}

The result of the research is that the school state of SDN Talaga kulon I is a school that has a variety of students in terms of religion and ethnicity, so it is suitable to do research with the aim to see the influence of learning game team tournament (TGT) model to increase cross-cultural skills. The result of the questionnaire that was executed during the pretest is as follows.

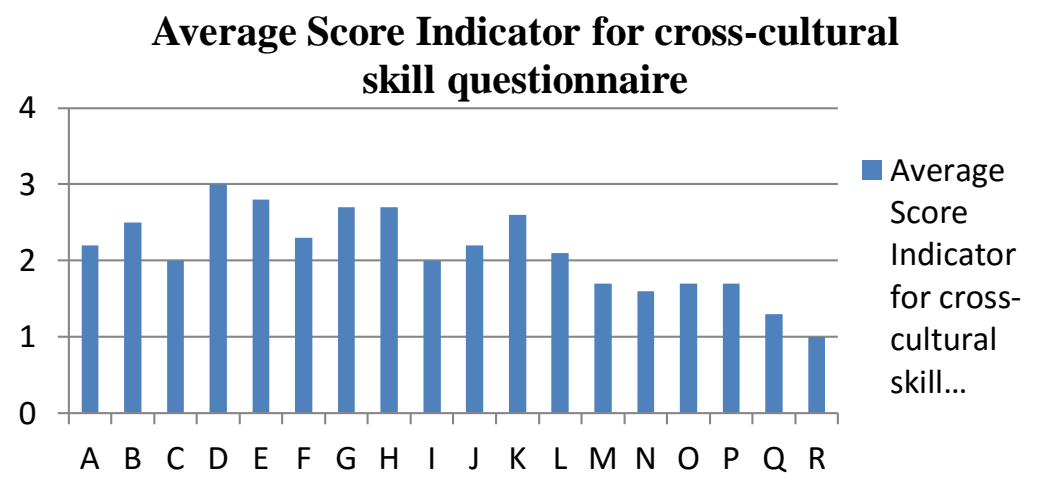

Garifk 1. Average Pretest Score Skills Cross - Cultural

Based on pretest results data above the statement items that got the highest average score is statement number four that is "Not distinguish friends by social status" with average 3 while the items that get the lowest average score that is item number eighteen is "Leveraging social and cultural differences to work effectively together" with an average of 1.0. After implementing the pretest and analyzing the pretest, the next step is to provide treatment using the game team tournament learning model (TGT) and held for two meetings. Before preparing the lesson using the teacher game tournament learning model (TGT) teacher prepares the necessary things such as analyzing syllabus and material related to cross-cultura skills and preparing lesson-based learning plan (RPP) game team tournament (TGT). After carrying out the lesson for two meetings, postes are held. The post ces cross cultural skills are as follows. 
Average Score Indicator for cross-cultural skill questionnaire

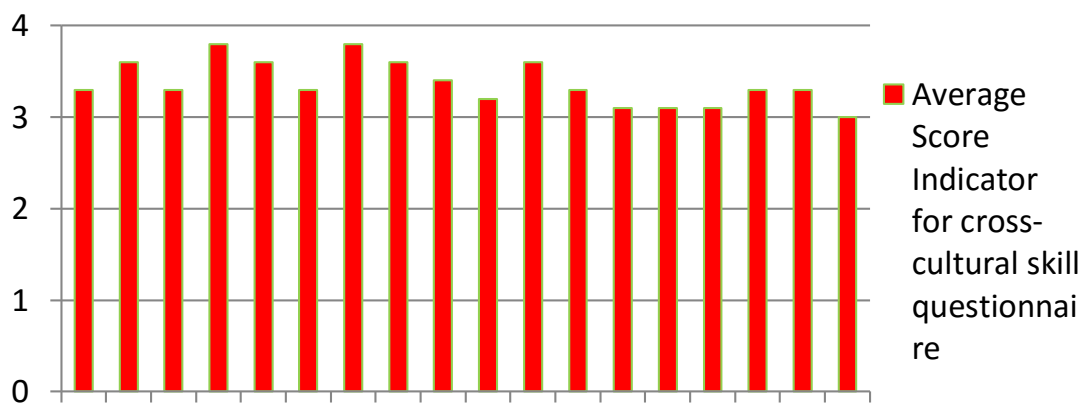

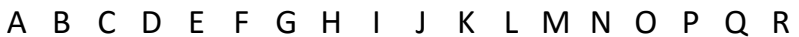

Garifk 2. Average Postes Score Skills Cross - Cultural

Based on the data of postes result above the statement item which got the highest average score is statement number eight that is "Ability to cooperate with individual with different cultural background" with average 3,8 whereas the item get the lowest average score namely point eighteen "Utilizing social and cultural differences to work effectively together" with an average of 3.0. To see the increasing difference between the pretest and posttest results of each questionnaire the N-Gain test was performed. The results of the N-Gain test are as follows.

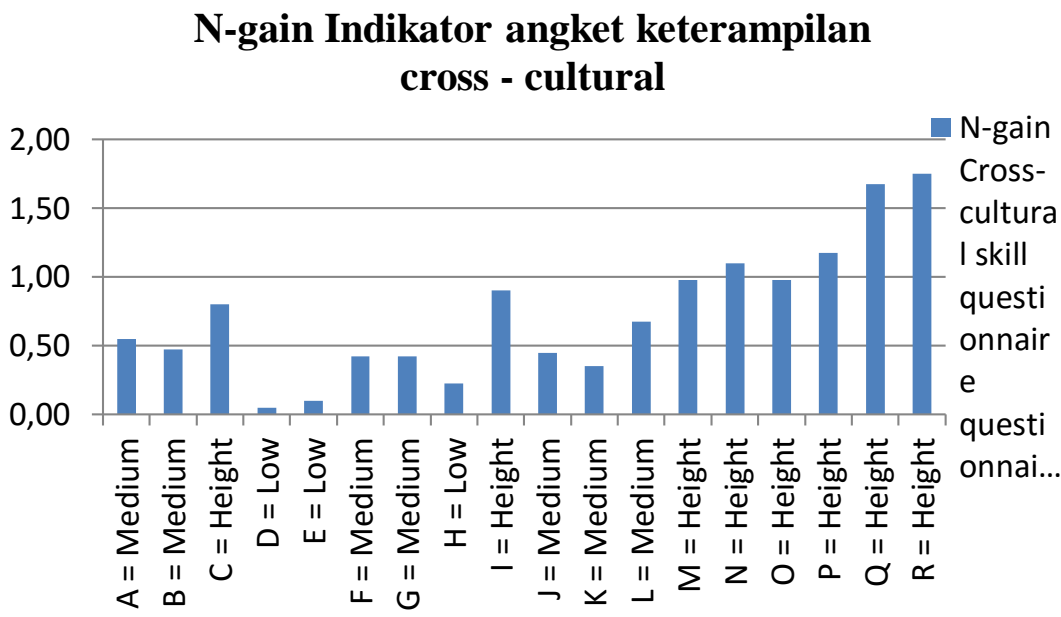

Graph 3. N-gain cross cultural skills

Viewed from the above garfik can be concluded that after learning using cooperative model of game team tournament type (TGT) cross-cultural skills have increased. The most elevated cross-culturic grain can be the eighteenth cross-cultural point of "Utilizing the social and cultural differences to work effectively" with $\mathrm{N}$-gain $=1.75$ while the lowest crosscultural increase is the fourth point of "Not Distinguish friends by social status" with N-gain $=0.05$. From the results of the research that has been exposed, learning using cooperative 
learning model type of game tournament team (TGT) gives a positive impact is seen an increase in cross-cultural skills. In the learning process using game tournament team (TGT) in this study found beberpa interesting things that become learning and can be used as input for research other research. The first interesting findings were first encountered during the observation of early ability on cross cultural skills.

The finding is that there are some students who have been sitting with no differentiating social status as there is a child merchant sitting with a doctor's son, a child TNI sitting with a child farmers and so forth. In this case the students already have cross-cultured skills on their own, but they are not aware of it and the teacher has not linked the students' initial ability to the classroom learning. Another finding occurred at the stage of treatment using the game team tournament model (TGT), ie students are not used to learn by grouping and discussing. There are some students who belong to the group of superior students in their class refused to be grouped with students who diaggapnya lower ability, some students also have refused grouped with students who are not playmates outside the classroom. This is a challenge for teachers because it requires patience in explaining the benefits of group learning.

\section{CONCLUSION}

Learning using cooperative model of game tournament team type (TGT) can improve cross-cultural skills of fourth grade students of SDN Talaga kulon I Kec. Talaha Kab. Majalengka. A significant cross-cultural indicator of cross-cultural skills is the eighteenthcentury cross-cultural indicator, "Utilizing social and cultural differences to work effectively" while the lowest cross-cultural indicator is the fourth item, "No discriminating based on social status ".

\section{ACKNOWLEDGMENTS}

Researchers of the IKIP Siliwangi, University of Kuningan, and SD Negri Talaga kulon I.

\section{REFERENCES}

Johnson, dkk. (2006). Cross-cultural competence in international business: toward a definition and a model. Journal of International Business Studies.37, hlm.525543.

Mudiyanto, H. (2016). Pengaruh model pembelajaran kooperatif tipe tgt (team game tournament) terhadap keterampilan cross-cultural dan hasil belajar siswa SD Kelas V pada pembelajaran IPS. Tesis tidak diterbitkan. Bandung: Pascasarjana UPI. 
Partnership For 21st Century Skill. (2008). 21st century skills, education and competitiveness. A resourche and policy guide. Tucson : Partnership For 21st Century Skill.

Septiyan, G. (2017). Pengaruh model teams games tournament terhadap keterampilan pengambilan keputusan dalam pembelajaran ips di sekolah dasar. Mimbar sekolah dasar, 4(1), 106-116.

Soegeng, A.Y. (2016). Dasar-dasar penelitian. Yogyakarta: Magnum Pustaka Utama.

Slavin, R. E. (2015). Cooperative learning. Bandung: Nusa Media.

Trilling \& Fadel. (2009). 21st century skills learning for life in our times. San Francisco : Jossey Bass. 